\title{
Erratum to: c-Kit proto-oncogene expression in endometrial hyperplasia and endometrial cancer
}

\author{
Ercan Yilmaz $\cdot$ Onder Celik · Yavuz Simsek • \\ Ilgin Turkcuoglu $\cdot$ Ebru Celik $\cdot$ Mehmet Gül · \\ Seyma Hascalik $\cdot$ Nasuhi Engin Aydin
}

Published online: 25 March 2012

(C) Springer-Verlag 2012

\section{Erratum to: Arch Gynecol Obstet}

DOI 10.1007/s00404-012-2276-8

Unfortunately the last author's given name was inadvertently omitted in the online published article. The complete name is Nasuhi Engin Aydin.

The online version of the original article can be found under doi:10.1007/s00404-012-2276-8.

E. Yilmaz $(\varangle) \cdot$ O. Celik · Y. Simsek · I. Turkcuoglu · E. Celik Department of Obstetrics and Gynecology,

Inonu University School of Medicine, 44100 Malatya, Turkey

e-mail: ercanyilmazgyn@yahoo.com

M. Gül

Department of Histology and Embryology,

Inonu University School of Medicine, Malatya, Turkey

S. Hascalik

Division of Obstetrics and Gynecology,

Park Hospital, Malatya, Turkey

N. E. Aydin

Department of Pathology, Inonu University School of Medicine,

Malatya, Turkey 